\title{
Feonomies
}

Central European Review of Economics \& Finance

Vol. 28, No. 6 (2018), pp. 25-38

DOI: $10.24136 /$ ceref.2018.029

Received: 12 October 2018. Accepted: 15 December 2018.

Michał WIERZBIĘTA ${ }^{1}$

\section{IMPACT OF THE ACCOUNTING STANDARDS APPLIED ON THE ASSESSMENT OF THE FINANCIAL SITUATION OF A COMPANY FROM THE MINING SECTOR}

The discrepancies between the Polish balance sheet law and the International Financial Reporting Standards (IFRS) with regard to the recognition and presentation of economic events may in some cases have a significant impact on the financial data of the entities applying selected standards. Having regard to the Polish legal system, which imposes the obligation to apply IFRS on listed entities, at the same time excluding this possibility for other entities, it is interesting to attempt to verify the potential comparability of specific companies with a similar profile, operating in the same industry. The aim of the paper is to identify and assess the impact of the accounting standards applied on the key financial ratios and data of an entity operating in the mining industry. The research method used in the paper is financial analysis. The data used for the analyses cover the years 2007-2015.

Keywords: finance, standard, accounting, company, mining.

JEL Classification Codes: L72, M41.

\section{Introduction}

Wide spreading IFRS adoption and its progressive evolution contribute to increased interest in the subject of differences between local accounting standards and IFRS and also changes introduced to international standards over time. Comparative analysis of differences between IFRS and Romanian Accounting Standards and its impact on

\footnotetext{
${ }^{1}$ certified auditor, wierzbieta@gmail.com
} 
financial statement of companies listed on Bucharest Stock Exchange (Georgescu et al. 2015) or comparison of IFRS and Chinese local standards based on review of the enforcement of the IFRS principles in China when they are used by Chinese companies listed on the Mainland Chinese Stock Exchanges (Rossetti S. Verona R., 2017) are examples of papers that emphasis significance of the subject in various countries.

Financial statements constitute a significant source of information about the financial condition of a company, and the data disclosed in such statements are the subject of interest of stakeholders such as investors, lenders, contracting parties, governments and their agencies, as well as the general public. According to the "Conceptual Framework for Financial Reporting" developed by the International Accounting Standards Board, the primary objective of financial statements is to provide information about the financial situation, business results and change in the entity's financial situation, which will be useful for a wide group of users when they make economic decisions (IFRS, 2004). The Conceptual Framework also points out that information may be considered useful if it is comparable, verifiable, timely, and understandable.

A significant role in this context is played by the form of presentation of the financial data, which translates into such qualitative characteristics as comparability and understandability of the information (Kędzior \& Grabiński, 2018). It needs to be pointed out that International Accounting Standard No. 1 gives entities substantial freedom when it comes to choosing the layout and contents of the financial statements, only indicating a list of the items that should be disclosed, while the Polish legislator defines the form of the statements precisely, providing a template in an annex to the Accounting Act (Polish Journal of Laws Dz.U. of 2018, item 395, as amended), hereinafter also referred to as the „Act”. According to the Polish legal system, which takes into account the provisions of Regulation (EC) No 1606/2002 of the European Parliament and of the Council of 19 July 2002 on the application of international accounting standards (OJ L 243, 11.9.2002), public companies are obligated to apply International Financial Reporting Standards (hereinafter the "IFRS"), while other entities apply Polish accounting principles set forth by the Accounting Act. Bearing in mind the above, users analysing financial statements need to be familiar with the Polish and international balance sheet law in order to be able to interpret the data and to compare the respective entities' financial situation correctly.

Full text of international accounting standards adopted by EU was introduced by Commission Regulation (EC) No 1126/2008 of 3 November 2008 adopting certain international accounting standards in accordance with Regulation (EC) No 1606/2002 of the European Parliament and of the Council (Dz. Urz. UE L of 2008, item 320/1, as amended).

The differences between the IFRS regulations and the Polish Accounting Act in terms of recognition and presentation of certain economic events and operations may lead to significant discrepancies in the structure of companies' financial statements, and consequently influence the assessment of the financial situation as well as the users' decisions made on the basis of such statements. Although literature on the subject so 
far has already analysed differences between the standards and their potential impact on financial statements (cf. Wędzki 2009, Adamkiewicz et al. 2014, Grabiński \& Kędzior 2007, Adamik-Citak 2011), both the scope of the discrepancies and the specific nature of the companies operating in different industries justify further exploration of the topic. The mining industry is one that displays such specificities. In the Polish hard coal mining sector, there are currently several large business entities, the majority of which, as companies listed on the Warsaw Stock Exchange (JSW SA, Bogdanka S.A.) or entities controlled by public companies, prepare reports according to IFRS. However, there are entities that are still reporting according to the Polish Accounting Act or have recently transitioned its statements to IFRS. This situation may make it difficult to assess and compare the economic resources and claims as well as the business performance of entities with a similar profile of operations. This is why the aim of the paper is to assess the impact of the differences appearing in financial statements prepared in accordance with the Polish accounting principles vs. IFRS on the financial situation of a group from the mining sector ${ }^{2}$. Financial analysis was applied as the research method, using selected ratios on the basis of the financial statements made available by the company, prepared in accordance with IFRS, and statutory financial statements prepared in accordance with the Accounting Act. The analyses spanned the years 2007-2015, with the date of transition to IFRS for the company being 1 January 2007. The company selected for the analysis prepared its statutory financial statements in the period discussed here in accordance with the Accounting Act, and financial statements in accordance with IFRS in relation to the requirements of the financing agreement. It is worth emphasising that both the statutory financial statements and the financial statements in accordance with IFRS were subject to audit by a certified auditor.

The results of the study may be significant both for government agencies acting as regulators and shareholders in the sector, and for other entities from the sector considering transition to IFRS.

\section{Description of the adjustments made by the group as of the date of transition to IFRS}

The main adjustments made by the company (group of companies, group) within the framework of data restatement should be considered to comprise:

1. Valuation of tangible fixed assets

The group, as of the date of transition to IFRS, i.e. 1 January 2007, measured tangible fixed assets acquired before that date using fair value as the assumed acquisi-

\footnotetext{
${ }^{2}$ The name of the group whose consolidated financial statements were analysed has been anonymised at the request of the company's representatives.
} 
tion cost. The adjustment was applied directly as a result of the exemption indicated in IFRS 1.13b, described more extensively in IFRS 1.16-1.18. Measurement of fixed assets at fair value led to a significant increase in their initial value, at the same time contributing to an increase in the entity's equity. The solution applied had the largest influence not only on the value and structure of assets and liabilities, but also on the financial profit/loss recognised in the consecutive years, affected by higher depreciation. Additionally, the increased value of non current assets may generate additional differences in subsequent reporting periods in the case of an impairment test. It should be pointed out that the criteria of asset impairment set forth in Polish Accounting Standard No. 4 coincide as a matter of principle with those defined in IAS 34 (cf. Adamkiewicz et al., 2014).

2. Presentation of capitalised costs of preparatory works

The parent company capitalises costs of preparatory works related to coal mining, which do not cause the production or acquisition of property, plant and equipment. Such expenditures are incurred for preparatory works related to mining output obtained in future periods. These expenditures were presented in financial statements made in accordance with the Act in the $2008^{3}$ to 2013 period as prepayments, divided into the short-term and the long term portion. In the restatement process, it was decided that the said assets were similar to property, plant and equipment in terms of their nature. This approach is also applied by companies from the coal mining sector listed on the Warsaw Stock Exchange which prepare their financial statements in accordance with IFRS (LW Bogdanka SA, JSW SA). Recognition of the entire value of capitalised costs of preparatory works in fixed assets influenced the asset structure significantly, increasing the value of non-current assets at the expense of current assets.

3. Presentation of assets held for sale

Non-current assets held for sale include assets (or groups thereof) in relation to which the economic benefits derived from ownership may be obtained by way of a sale transaction, rather than through continued use. This situation occurs when a fixed asset is available for immediate sale in its current state, taking into account only normal and customarily accepted conditions of sale, and its sale is highly probable (Seredyński et al., 2009).

According to IFRS 5, the entity must present non-current assets classified as held for sale, and the assets included within a disposal group classified as held for sale, separately on the face of the statement of financial position. A similar approach is applied with regard to liabilities related to the disposal group, which must also be presented separately in liabilities. Offsetting assets and liabilities is not allowed

\footnotetext{
${ }^{3}$ The data in accordance with the Accounting Act for the year 2007 were restated appropriately for the purposes of this paper.
} 
(IFRS 5.38) In practice, taking into account the liquidity criterion, these assets are presented in current assets (cf. Piotr Prewysz-Kwinto, Grażyna Voss, 2016). Assets held for sale are measured at the lower of carrying amount and fair value less costs to sell (cf. IFRS 5.15). The Polish balance sheet law does not regulate the aspect of assets held for sale, nor, in particular, does it envisage the possibility of excluding assets intended for disposal from non-current assets. Consequently, classifying assets as available for sale entails a change in the asset structure.

4. Net presentation of deferred tax

For the purposes of preparation of financial statements in accordance with the Polish accounting standards (Accounting Act), the Group presented the deferred income tax asset and provision separately in assets and liabilities in the statement of financial position.

According to IAS 12.73, in consolidated financial statements, a current tax asset of one entity in a group is offset against a current tax liability of another entity in the group if, and only if, the entities concerned have a legally enforceable right to make or receive a single net payment and the entities intend to make or receive such a net payment or to recover the asset and settle the liability simultaneously (IAS 12.73). It is worth pointing out that the IAS 12.72 provisions quoted above represent an exception from the general rule defined in IAS 1, according to which the entity should not offset assets and liabilities or revenues and expenses, because it detracts from the ability of users both to understand the transactions, other events and conditions that have occurred and to assess the entity's future cash flows (IAS 1.32-1.33). Offsetting assets and liabilities may lead to a significant decrease in the balance sheet total, improving at the same time the capital gearing ratio.

5. Company Social Benefits Fund assets

In accordance with the Act of 4 March 1994 on the company social benefits fund (Dz. U. of 2018, item 1316), entities which are part of the analysed capital group establish a Company Social Benefits Fund (ZFŚS) and manage it on behalf of their employees. The contributions towards the Company Social Benefits Fund are deposited in separate bank accounts of the respective entities. In the group's consolidated financial statements in accordance with the Accounting Act, the assets financing the Company Social Benefits Fund are recognised as monetary assets, receivables or prepayments (IFRS financial statements, 2007-2009, 2011). Special funds are not regulated by IFRS, which in practice has led to discrepancies in the recognition of assets and liabilities related to the funds. Some companies, including companies from the analysed group, recognise events related to the company social benefits fund only in the financial profit/loss, while assets and liabilities are removed from the statement of financial position. This solution is justified by the fact that the Company Social Benefits Fund assets, being beyond the entity's control, do not meet the definition of assets included in the conceptual framework. Given the absence of regulation 
in IFRS, some entities apply the provisions of the Polish balance sheet law in this regard, in accordance with the provisions of Article 2.3 of the Accounting Act, which clearly indicates that the Act and the implementing rules issued on its basis shall be applied in cases not governed by IAS (cf. Seredyński, Krupa, Stawowy, JałowieckaMadeja, 2009). The Company Social Benefits Fund assets were not recognised in consolidated financial statements in accordance with IFRS, due to the absence of expected economic benefits which could potentially lead to cash and cash equivalents crediting the Group's account (IFRS financial statements 2007-2009, 2011). The exclusion of Company Social Benefits Fund assets and liabilities in the IFRS financial statements often leads to a decrease in the recognised amount, and consequently worse liquidity ratios compared to the same ratios calculated on the basis of financial statements prepared in accordance with the Accounting Act.

6. Recognising contributions to the Mine Liquidation Fund (FLZG) and presentation of assets and provisions related thereto in the statement of financial position.

Pursuant to the Act of 4 February 1994 - Geological and Mining Law (Dz. U. of 2011 no. 163, item 981), the group companies established provisions for the liquidation of mines, made contributions to the Mine Liquidation Fund, and transferred funds to separate accounts, but the presentation of the related assets and liabilities and the method of cost recognition differed in the financial statements prepared in accordance with IFRS compared to the recognition in the statements in accordance with the Accounting Act in the following manner:

a) with regard to assets, the estimated costs of dismantling and removal of an asset according to IAS 16.16c increase the production or acquisition of fixed assets. According to the Accounting Act property, plant and equipment is recognised at the acquisition or production cost which do not include the estimated future costs of dismantling;

b) with regard to liabilities in the financial statements in accordance with the Accounting Act, the provision for the costs of plant liquidation is presented in long-term provisions, while the balance of the liquidation fund is presented in special fund payables. In the financial statements in accordance with IFRS, it is presented entirely in provisions;

c) in the income statement in accordance with IFRS, depreciation of the capitalised portion of the liquidation costs is charged to operating expenses, which is a consequences of recognising this category as an element of the initial value of property, plant and equipment item;

d) the Mine Liquidation Fund cash, constituting restricted cash in the group's financial statements prepared in accordance with IFRS, is presented as other longterm financial assets, reflecting the degree of liquidity of the relevant asset.

The adjustment applied as above with regard to the recognition and presentation of the Mine Liquidation Fund in the financial statements in accordance with IFRS had 
an impact, therefore, on the structure of the balance sheet and of the income statement, as well as on the cash flow statement.

\section{Assessment of the impact of transition to IFRS on the entity's financial data}

The main categories of data presented in the financial statements were analysed to assess the influence of the standards applied on the group's financial data. Table 1 presents the differences in the value of assets as of the date of transition to IFRS and as of the subsequent balance sheet dates.

Table 1. Changes in the value of non-current and current assets as a result of transition to IFRS [millions PLN]

\begin{tabular}{|c|c|c|c|c|c|c|c|c|c|c|}
\hline & \begin{tabular}{|c|}
01 Jan \\
2017
\end{tabular} & $\begin{array}{c}31 \mathrm{Dec} \\
2007\end{array}$ & $\begin{array}{c}31 \mathrm{Dec} \\
2008\end{array}$ & $\begin{array}{c}31 \mathrm{Dec} \\
2009\end{array}$ & $\begin{array}{c}31 \mathrm{Dec} \\
2010\end{array}$ & $\begin{array}{c}31 \mathrm{Dec} \\
2011\end{array}$ & $\begin{array}{c}31 \mathrm{Dec} \\
2012\end{array}$ & $\begin{array}{c}31 \mathrm{Dec} \\
2013\end{array}$ & $\begin{array}{c}31 \mathrm{Dec} \\
2014\end{array}$ & $\begin{array}{c}31 \mathrm{Dec} \\
2015\end{array}$ \\
\hline \multicolumn{11}{|c|}{ Financial statements in accordance with the Act } \\
\hline Total assets, including & 3,284 & 3,420 & 4,106 & 4,819 & 4,736 & 4,710 & 5,485 & 5,716 & 5,158 & 4,386 \\
\hline Non-current assets & 2,375 & 2,565 & 3,070 & 3,662 & 3,761 & 3,777 & 4,167 & 4,331 & 4,244 & 3,690 \\
\hline Current assets & 910 & 855 & 1,035 & 1,157 & 976 & 932 & 1,318 & 1,385 & 914 & 696 \\
\hline \multicolumn{11}{|c|}{ Financial statements in accordance with IFRS } \\
\hline Total assets, including & 5,204 & 5,054 & 5,433 & 5,847 & 5,560 & 5,343 & 5,954 & 6,032 & 5,590 & 4,505 \\
\hline Non-current assets & 4,482 & 4,402 & 4,664 & 5,014 & 4,883 & 4,702 & 5,023 & 5,113 & 4,719 & 3,828 \\
\hline Current assets & 722 & 651 & 769 & 834 & 677 & 641 & 931 & 919 & 871 & 677 \\
\hline \multicolumn{11}{|c|}{ Difference / change as a result of restatement } \\
\hline Total assets, including & 1,920 & 1,633 & 1,328 & 1,028 & 823 & 634 & 469 & 316 & 432 & 118 \\
\hline Non-current assets & 2,107 & 1,837 & 1,593 & 1,352 & 1,122 & 925 & 857 & 782 & 475 & 138 \\
\hline Current assets & -188 & -204 & -266 & -324 & -298 & -291 & -387 & -466 & -43 & -19 \\
\hline \multicolumn{11}{|c|}{ Difference / change as a result of restatement (expressed in \%) } \\
\hline Total assets, including & 58 & 48 & 32 & 21 & 17 & 13 & 9 & 6 & 8 & 3 \\
\hline Non-current assets & 89 & 72 & 52 & 37 & 30 & 24 & 21 & 18 & 11 & 4 \\
\hline Current assets & -21 & -24 & -26 & -28 & -31 & -31 & -29 & -34 & -5 & -3 \\
\hline
\end{tabular}

Source: own compilation based on the company's financial statements.

The comparison points to a clear increase in the value of assets, caused mainly by the measurement of fixed assets as of the date of transition to IFRS. Interestingly, the result of the above analysis differs from the results of the analyses carried out for listed companies in the period of transition to IFRS. The analysis of the consequences of transition to IFRS in 2004 carried out on the basis of 30 groups listed on the Warsaw Stock Exchange demonstrated that restatement of the financial statements in accordance with International Accounting Standards had only an insignificant impact on the financial data. 
According to the outcomes of the research, total assets increased by $2 \%$ on average as a result of the transition to IFRS. It is worth pointing out, however, that fixed assets were the main drivers of growth, increasing by $5 \%$ on average (cf. Grabiński \& Kędzior, 2007).

In the analysed case, the reason for the significant change in the value of assets may be provided by the valuation of land and of the right of perpetual usufruct of land, whose value grows over time. The last revaluation of fixed assets in polish balance sheet law was performed as of 1 January 1995 on the basis of the Ordinance of the Minister of Finance of 20 January 1995 on depreciation of property, plant and equipment and amortisation of intangible assets, and on property, plant and equipment valuation (Dz. U. No. 7, item 34, as amended). With regard to underground headings, which constitute a significant element of the mines' assets, the valuation is most likely to have been performed using the replacement method, so the values could grow significantly. With regard to the remaining groups of assets, this may be caused by the overly high depreciation rates applied in the previous periods, leading to an inappropriate decrease in the value of the assets held.

An analysis of the data over time clearly points to the temporary nature of the difference. The higher value of assets in the subsequent periods translates into increased depreciation, leading to a decrease in the financial results in the financial statements prepared in accordance with IFRS compared to the financial statements prepared in accordance with the Accounting Act. The values of the depreciation costs are compared in Table 2.

Table 2. Comparison of depreciation value in financial statements in accordance with the Act and IFRS [millions PLN]

\begin{tabular}{|l|r|r|r|r|r|r|r|r|r|}
\hline Depreciation value & 2007 & $\mathbf{2 0 0 8}$ & $\mathbf{2 0 0 9}$ & $\mathbf{2 0 1 0}$ & $\mathbf{2 0 1 1}$ & $\mathbf{2 0 1 2}$ & $\mathbf{2 0 1 3}$ & $\mathbf{2 0 1 4}$ & $\mathbf{2 0 1 5}$ \\
\hline PAS statements & -254 & -280 & -369 & -422 & -460 & -470 & -425 & -917 & -834 \\
\hline IFRS statements & -489 & -484 & -545 & -565 & -530 & -513 & -452 & -943 & -850 \\
\hline Difference & -236 & -204 & -177 & -143 & -70 & -44 & -27 & -27 & -16 \\
\hline
\end{tabular}

Source: own compilation based on the company's financial statements.

A comparison of assets also points to a significant decrease in current assets, caused mainly by reclassification to fixed assets of the prepayments related to capitalised costs of preparatory works. Another significant adjustment consists in the reclassification of the financial assets of the Mine Liquidation Fund to long-term investments.

The change in the structure of assets as a result of the adjustments leads to a reduction in the group's net working capital defined as current assets less short-term liabilities, and thus has a negative impact on the assessment of the company's financial situation in terms of liquidity. Table 3 presents a comparison of the net working capital values. 
Table 3. Differences in the value of net working capital as a result of restatement of data in accordance with IFRS [millions PLN]

\begin{tabular}{|l|c|c|c|c|c|c|c|c|c|c|}
\hline & $\begin{array}{c}01 \text { Jan } \\
2017\end{array}$ & $\begin{array}{c}31 \text { Dec } \\
2007\end{array}$ & $\begin{array}{c}31 \text { Dec } \\
2008\end{array}$ & $\begin{array}{c}31 \text { Dec } \\
2009\end{array}$ & $\begin{array}{c}31 \text { Dec } \\
2010\end{array}$ & $\begin{array}{c}31 \text { Dec } \\
2011\end{array}$ & $\begin{array}{c}31 \text { Dec } \\
2012\end{array}$ & $\begin{array}{c}31 \text { Dec } \\
2013\end{array}$ & $\begin{array}{c}31 \text { Dec } \\
2014\end{array}$ & $\begin{array}{c}31 \text { Dec } \\
2015\end{array}$ \\
\hline Financial statements in accordance with the Act \\
\hline Current assets & 910 & 855 & 1,035 & 1,157 & 976 & 932 & 1,318 & 1,385 & 914 & 696 \\
\hline Current liabilities & 860 & 1,020 & 1,573 & 2,003 & 1,843 & 1,723 & 1,638 & 1,795 & 2,244 & 1,491 \\
\hline \multicolumn{10}{|c|}{ Financial statements in accordance with IFRS } \\
\hline Current assets & 722 & 651 & 769 & 834 & 677 & 641 & 931 & 919 & 871 & 677 \\
\hline Current liabilities & 846 & 949 & 1,485 & 1,929 & 1,781 & 1,641 & 1,551 & 1,694 & 2,173 & 1,455 \\
\hline \multicolumn{10}{|c|}{ Net working capital = current assets - current liabilities } \\
\hline PAS statements & 49 & -164 & -538 & -845 & -868 & -791 & -320 & -410 & $-1,329$ & -795 \\
\hline IFRS statements & -124 & -297 & -715 & $-1,095$ & $-1,104$ & -999 & -620 & -775 & $-1,302$ & -778 \\
\hline Difference & -173 & -133 & -177 & -250 & -236 & -209 & -300 & -365 & 28 & 16 \\
\hline
\end{tabular}

Source: own compilation based on the company's financial statements.

The data presented in Table 3 show the influence of the adjustments on the group's net working capital. With regard to current liabilities, the main difference between the statements concerns the adjustment related to liabilities of the Mine Liquidation Fund, recognised together with a long-term provision.

The significant reduction of the difference in the value of net working capital between the statements from 2014 results from the adjustment to the accounting principles introduced by the group in the financial statements prepared in accordance with the Accounting Act with regard to the presentation of capitalised costs of preparatory works and to the principles of their depreciation. According to the information presented in the notes to the statutory financial statements of the group prepared in accordance with the Accounting Act, the change was caused precisely by the effort to achieve a consistent approach in the whole industry, with an emphasis on the practice applied by companies from the coal sector listed on the Warsaw Stock Exchange (PAS financial statements $2014,2015)$. The change in the policy that was made concerned the reclassification of prepayments to fixed assets and the recognition of the current use of the asset as depreciation, which explains the changes in Table 2 presenting a comparison of that cost category.

In the context of the impact of the application of IFRS on the balance sheet structure, it is worth looking at the ratios based on the relations between the individual categories of assets and liabilities. Table 4 presents two basic ratios related to the structure of liabilities:

1. Sustainability of the financing structure ratio, supposed to determine the share of capital employed in the total value of assets. It refers to the golden balance sheet rule, according to which source of financing may not be connected to specific assets 
for a time longer than the time over which the same source of financing remains within the company (Gabrusewicz, 2005). According to the rule described above, the optimal value of the ratio should be more or less one.

2. Debt to equity ratio, providing information about the degree of employment of external sources of financing compared to own sources. This ratio measures the company's indebtedness. It is difficult to determine, however, how many times debt capital may exceed equity capital (Gabrusewicz, 2005).

Table 4. Comparison of financing structure sustainability and debt to equity ratios [millions PLN]

\begin{tabular}{|l|c|c|c|c|c|c|c|c|c|c|}
\hline & $\begin{array}{c}01 \mathrm{Jan} \\
2017\end{array}$ & $\begin{array}{c}31 \text { Dec } \\
2007\end{array}$ & $\begin{array}{c}31 \text { Dec } \\
2008\end{array}$ & $\begin{array}{c}31 \text { Dec } \\
2009\end{array}$ & $\begin{array}{c}31 \text { Dec } \\
2010\end{array}$ & $\begin{array}{c}31 \text { Dec } \\
2011\end{array}$ & $\begin{array}{c}31 \text { Dec } \\
2012\end{array}$ & $\begin{array}{c}31 \text { Dec } \\
2013\end{array}$ & $\begin{array}{c}31 \text { Dec } \\
2014\end{array}$ & $\begin{array}{c}31 \text { Dec } \\
2015\end{array}$ \\
\hline \multicolumn{8}{|c|}{ Financial statements in accordance with the Act } \\
\hline $\begin{array}{l}\text { Financing structure } \\
\text { sustainability }\end{array}$ & 0.68 & 0.65 & 0.57 & 0.53 & 0.54 & 0.59 & 0.66 & 0.65 & 0.53 & 0.62 \\
\hline Debt to equity ratio & 1,62 & 1,75 & 2,27 & 2,64 & 2,49 & 2,14 & 2,97 & 3,06 & 8,60 & 8,44 \\
\hline \multicolumn{8}{|c|}{ Financial statements in accordance with IFRS } \\
\hline $\begin{array}{l}\text { Financing structure } \\
\text { sustainability }\end{array}$ & 0.80 & 0.78 & 0.70 & 0.62 & 0.63 & 0.66 & 0.71 & 0.69 & 0.58 & 0.65 \\
\hline Debt to equity ratio & 0.75 & 0.82 & 1.11 & 1.43 & 1.44 & 1.37 & 1.92 & 2.08 & 3.67 & 5.68 \\
\hline \multicolumn{8}{|c|}{ Differences } \\
\hline $\begin{array}{l}\text { Financing structure } \\
\text { sustainability }\end{array}$ & 0.12 & 0.13 & 0.12 & 0.10 & 0.08 & 0.07 & 0.05 & 0.04 & 0.05 & 0.02 \\
\hline Debt to equity ratio & -0.87 & -0.94 & -1.16 & -1.21 & -1.05 & -0.77 & -1.05 & -0.97 & -4.93 & -2.75 \\
\hline
\end{tabular}

Source: own compilation based on the company's financial statements.

The financing structure sustainability ratios calculated on the basis of the financial statements in accordance with IFRS are higher than the corresponding ratios calculated on the basis of the financial statements in accordance with the Accounting Act. The situation is reversed in the case of the debt to equity ratio. This means that, in the context discussed here, the financial statements in accordance with IFRS present a more favourable picture of the company compared to financial statements in accordance with the Accounting Act. Valuation of fixed assets had the most significant impact on this situation, and its results were reflected in the respective equity figures. One should note the downward trend in the differences between the ratios, resulting from the gradual reduction in the value of the assets as a result of depreciation.

It is also worth pointing to the negative impact of the increase in the value of fixed assets on the assessment of the company's profitability. The trend is reflected by:

1) the fixed asset turnover ratio, providing information on how effectively fixed assets are used in the company; 
2) the return on assets ratio, representing the profit-generating capacity of the company's assets;

3) the return on equity ratio (Jantoń-Drozdowska, Mikołajewicz-Woźniak, 2017).

Table 5 presents the differences between the ratios calculated for financial statements in accordance with the Accounting Act and IFRS.

Table 5. Comparison of profitability ratios

\begin{tabular}{|l|c|c|c|c|c|c|c|c|c|}
\hline & 2007 & 2008 & 2009 & 2010 & 2011 & 2012 & 2013 & 2014 & 2015 \\
\hline \multicolumn{10}{|c|}{ Financial statements in accordance with the Act } \\
\hline Fixed asset turnover & 1.28 & 1.25 & 1.21 & 1.06 & 1.12 & 1.00 & 0.94 & 0.78 & 0.79 \\
\hline Return on assets & 0.01 & 0.00 & 0.02 & 0.01 & 0.04 & 0.01 & 0.01 & -0.03 & -0.02 \\
\hline Return on equity & 0.02 & 0.01 & 0.07 & 0.03 & 0.12 & 0.02 & 0.03 & -0.17 & -0.17 \\
\hline \multicolumn{10}{|c|}{ Financial statements in accordance with IFRS } \\
\hline Fixed asset turnover & 0.71 & 0.78 & 0.84 & 0.80 & 0.88 & 0.82 & 0.79 & 0.68 & 0.73 \\
\hline Return on assets & -0.03 & -0.04 & -0.02 & -0.02 & 0.00 & -0.01 & -0.01 & -0.01 & -0.07 \\
\hline Return on equity & -0.06 & -0.07 & -0.05 & -0.05 & 0.01 & -0.02 & -0.03 & -0.03 & -0.39 \\
\hline \multicolumn{10}{|c|}{ Differences } \\
\hline Fixed asset turnover & -0.57 & -0.47 & -0.37 & -0.27 & -0.24 & -0.18 & -0.15 & -0.10 & -0.05 \\
\hline Return on assets & -0.04 & -0.04 & -0.04 & -0.03 & -0.03 & -0.01 & -0.02 & 0.02 & -0.05 \\
\hline Return on equity & -0.08 & -0.08 & -0.12 & -0.08 & -0.12 & -0.04 & -0.06 & 0.14 & -0.21 \\
\hline
\end{tabular}

Source: own compilation based on the company's financial statements.

In line with the expectations, the increase in the value of assets led to a reduction in the asset turnover ratios. The return on assets and return on equity ratios calculated on the basis of the financial statements in accordance with IFRS are negative, which results from the losses in the financial statements following the restatement. The decrease in financial performance is caused mainly by the fact that valuation of fixed assets was taken into account, leading to increased depreciation, increased revaluation write-downs on assets, and higher costs of fixed assets sold and liquidated. It was determined, on the basis of an analysis of the notes to the company's financial statements, that the differences related to asset valuation were among the main aspects generating discrepancies in the company's results, while a detailed analysis of the remaining reasons for the differences in the company's financial results goes beyond the scope of this paper.

The impact of the restatement on the liquidity analysis was assessed using the current ratio and the cash ratio, defining liquidity statically (cf. Table 6). 
Table 6. Comparison of liquidity ratios

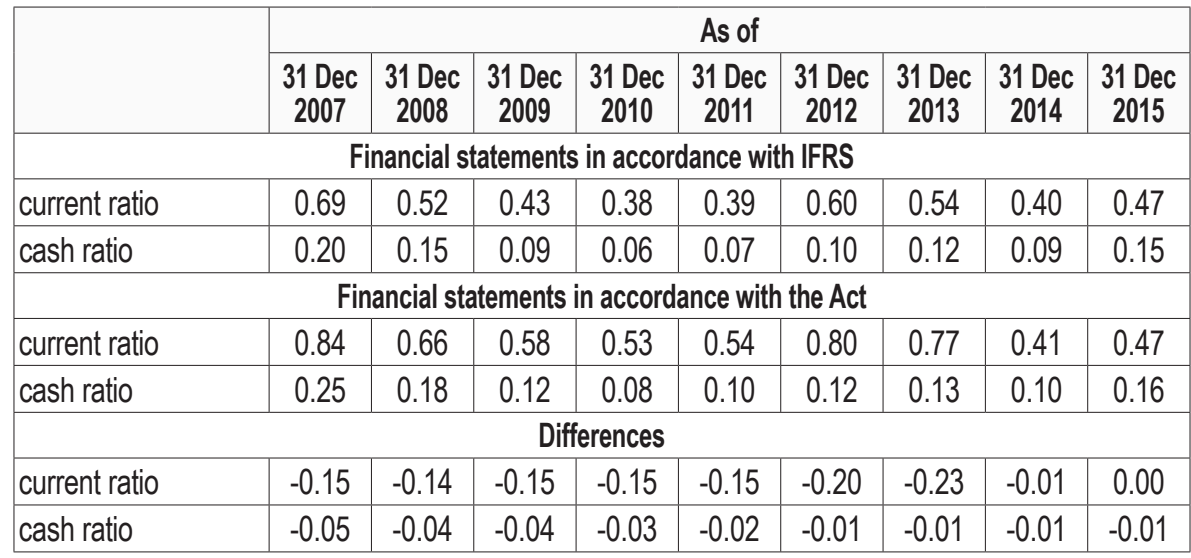

Source: own compilation based on the company's financial statements.

The financial liquidity ratios calculated on the basis of the financial statements in accordance with IFRS are lower, which results mainly from the adjustments related to recognition and presentation of special funds, as well as from the reclassification of prepayments to fixed assets. With regard to the special funds, it may be determined that the adjustments made influenced as a matter of principle both assets and liabilities, so their impact was limited to the difference between the balance of special funds and the value of the assets in those funds.

The change of classification of prepayments related to preparatory works influenced assets only, so its impact on the current ratio is visible, but it has no impact on the cash ratio. It is worth pointing out that the relation of the current ratio has changed since 2014. The change was caused by the modifications made to the accounting policy in the financial statements in accordance with the Accounting Act with regard to the presentation of capitalised costs of preparatory works.

\section{Conclusion}

The results of the analyses carried out point to an impact of differences resulting from the restatement of data to IFRS on the key ratios describing the company's situation. It should be pointed out, however, that the main source of the changes in the analysed case was the measurement of property, plant and equipment at fair value applied as of the transition date, in relation to which the identified differences are temporary in their nature, and their impact decreases as amortisation of the assets progresses. The remaining adjustments concern mainly differences in the presentation of assets and liabilities, which only translates into the balance sheet structure. The absence of an accurate definition of the layout of financial statements in IFRS creates favourable con- 
ditions for presentation that gives in a better manner a true and fair view of the given entity, which can be observed using the example of classification of prepayments related to preparatory works, with regard to which the entity, bearing in mind the problems with comparability versus listed companies operating in the sector, decided to change their presentation in the statutory financial statements in accordance with the Accounting Act, starting from 2014. The results of the analyses performed may contribute to a better understanding of the discrepancies if specific companies from the sector are compared that prepare financial statements based on different legal frameworks. The awareness of the impact of the standards applied on the financial statements is significant for stakeholders such as capital providers that assess the relevant entity by comparing it to the industry, as well as for government agencies such as the statistical office, which should take into account the differences in the classification and presentation of economic events when compiling data for the industry.

\section{References}

Adamik-Citak M. (2011). Porównanie informacji zawartej w sprawozdaniu finansowym prezentowanym według MSSF ze sprawozdaniem finansowym sporządzonym zgodnie z polskim prawem bilansowym, Zeszyty Teoretyczne Rachunkowości, t. 60(116).

Adamkiewicz Z., Samolik M., Zawadzki P., Supera K., Tendera P. (2014). Kompletny Obraz. Praktyczny przewodnik po MSSF, Infor Biznes Sp. z 0.0., Warszawa

Gabrusewicz W. (2005). Podstawy analizy finansowej, Polskie Wydawnictwo Ekonomiczne, Warszawa.

Georgescu I.E. Huţanu căs. Toma L., Afrăsinei B. (2015). Analysis of the impact of adopting the IFRS by the companies listed on BVB, Procedia Economics and Finance 20. https://www. sciencedirect.com/science/article/pii/S2212567115000738, accessed on 20.12.2018

Grabiński K., Kędzior M. (2007). Bilanse według ustawy o rachunkowości i Międzynarodowych Standardów Rachunkowości, Rachunkowość nr 11.

Jantoń-Drozdowska E., Mikołajewicz-Woźniak A. (2017). Analiza Finansowa jako narzędzie zarządzania przedsiębiorstwem, Wydawnictwo Naukowe UAM, Poznań.

Kędzior M., Grabiński K. (2018). Forma prezentacji informacji w sprawozdaniach finansowych a ich użyteczność - przegląd wybranych zagadnień, Zeszyty Naukowe Uniwersytetu Ekonomicznego w Krakowie 2(974).

Krajowy Standard Rachunkowości nr 11 Środki Trwałe (Dz. Urz. Ministra Rozwoju i Finansów z dnia 29 maja 2017 poz.105).

Lament M. (2017). Quality of non-financial information reported by financial institutions. The example of Poland and Greece, Central European Review of Economics \& Finance, Vol. 22, No. 6. 
Międzynarodowe Standardy Sprawozdawczości Finansowej (2004). International Accounting Standard Board, IFRS Foundation, London.

Prewysz-Kwinto P., Voss G. (2016). Aktywa trwałe przeznaczone do sprzedaży w sprawozdaniach Finansowych największych grup kapitałowych notowanych na GPW w Warszawie, Studia Ekonomiczne. Zeszyty Naukowe Uniwersytetu Ekonomicznego w Katowicach, nr 268.

Rossetti S. Verona R. (2017). International Differences in IFRS Policy Choice and the Persistence of Accounting Classification: The Case of China, International Journal of Business and Management; Vol. 12, No. 2.

Rozporządzenie Komisji (WE) nr 1126/2008 z dnia 3.11.2008 r. przyjmujące określone międzynarodowe standardy rachunkowości zgodnie z rozporzadzeniem (WE) nr 1606/2002 Parlamentu Europejskiego i Rady (Dz. Urz. UE L z 2008 r. nr 320/1 ze zm.).

Rozporządzenie (WE) nr 1606/2002 Parlamentu Europejskiego i Rady Unii Europejskiej z 19.07.2002 r. w sprawie stosowania Międzynarodowych Standardów Rachunkowości, Dz.U. WE L 243 z 11.09.2002.

Rozporządzenie Ministra Finansów z dnia 20 stycznia 1995 r. w sprawie amortyzacji środków trwałych oraz wartości niematerialnych i prawnych, a także aktualizacji wyceny środków trwałych (Dz. U. nr 7, poz. 34 ze zm.).

Seredyński R., Krupa M., Stawowy A., Jałowiecka-Madeja S. (2009). Międzynarodowe Standardy Rachunkowości, Wydawnictwo Poltext, Warszawa.

Skonsolidowane sprawozdania finansowe grupy kapitałowej za lata 2007-2015 sporzadzone wg MSSF.

Skonsolidowane sprawozdania finansowe grupy kapitałowej za lata 2007-2015 sporządzone wg Ustawy o Rachunkowości.

Ustawa z dnia 4.03.1994 r. o zakładowym funduszu świadczeń socjalnych (Dz. U. z 2018 r. poz. 1316).

Ustawa z dnia 29 września 1994 roku o rachunkowości (Dz. U. z 2018 r. poz. 395 ze zm.) Ustawa z dnia 4 lutego 1994 roku Prawo geologiczne i górnicze (Dz. U. z 2011 r. nr 163, poz. 981). Wędzki D. (2009). Analiza wskaźnikowa Sprawozdania finansowego, t. 1, Wolters Kluwer Polska, Kraków. 